\title{
SUGGESTIONS FOR IMPROVING THE EFFICIENCY AND EFFECTIVENESS OF QUALITY MANAGEMENT IN THE BUSINESS PRACTICE IN SLOVAKIA
}

\author{
MARTA KUČEROVÁ, JAROMÍRA VAŇOVÁ, DAGMAR RUSKOVÁ
}

\section{INTRODUCTION}

Quality management is a very dynamic category and in relation to the continuous development of society under changing conditions it acquires a new meaning. At present it is not enough, if the organization provides quality products that meet the customers' requirements, they must take into account the interests of all parties as well as accepting the environmental requirements. In this sense, the concept of quality has continuously started to have a broader content and development that gradually leads to the widest possible understanding, i.e. the "quality of life". In practice this means that the understanding of quality of products and services must also implement the limiting conditions which involve the qualitative aspects of all activities involved in order to provide for the human needs, interests and aspirations. A crucial aspect of understanding quality therefore becomes an extension to new factors, particularly on the environment but also concerning social and cultural aspects.

A prerequisite of improving the quality of products, reducing costs of enterprise and increasing productivity is to have suitably configured processes within quality management.

There are three principal dimensions for measuring process quality: effectiveness, efficiency and adaptability. The process is effective if the output meets customer needs. It is efficient when it is effective at the least cost. The process is adaptable when it remains effective and efficient in the face of the many changes that occur over time. A process orientation is vital if management is to meet customer needs and ensure organizational health (Juran et al, 1998).

The vast majority of organizations in Slovakia currently have built a quality management system, but not all organizations are applying the basic principles on a sufficiently needed level. Within the research project we have looked at issues of quality management applications in various branches of industrial practice. Theoretically, we elaborated the knowledge on the normative security of quality management for individual branches of industry and through research we assessed the level of applied fundamental principles, which the quality management systems are designed on. 
Positive effects of quality improvement are reflected especcialy in profit of enterprise. Techniques of quality improvement should be implemented in all organisation structures of enterprise (Vaňová \& Kučerová, 2010).

\section{A SURVEY STUDIED THE APPLICATION OF THE BASIC PRINCIPLES OF QUALITY MANAGEMENT IN PRACTICE}

Quality management is currently based on eight basic principles and applies to design standards for building and certifying quality management systems and also total quality management philosophy. The goal of the standard is to improve the quality of products and services being provided to the consumer to fulfiil also requirements for certification (Fidlerová, 2005).

In the period of 2009 and 2010, we implemented in the project VEGA the survey which was conducted by the questionnaire method. We assessed the level of fundamental principles application, on which the quality management systems are conceived. It was attended by 135 organizations from various industries. The object of their activities was the manufacture of products or providing services. The structure of the surveyed file in terms of size of the organization depending on the number of employees is given in a graphical representation in Figure 1.

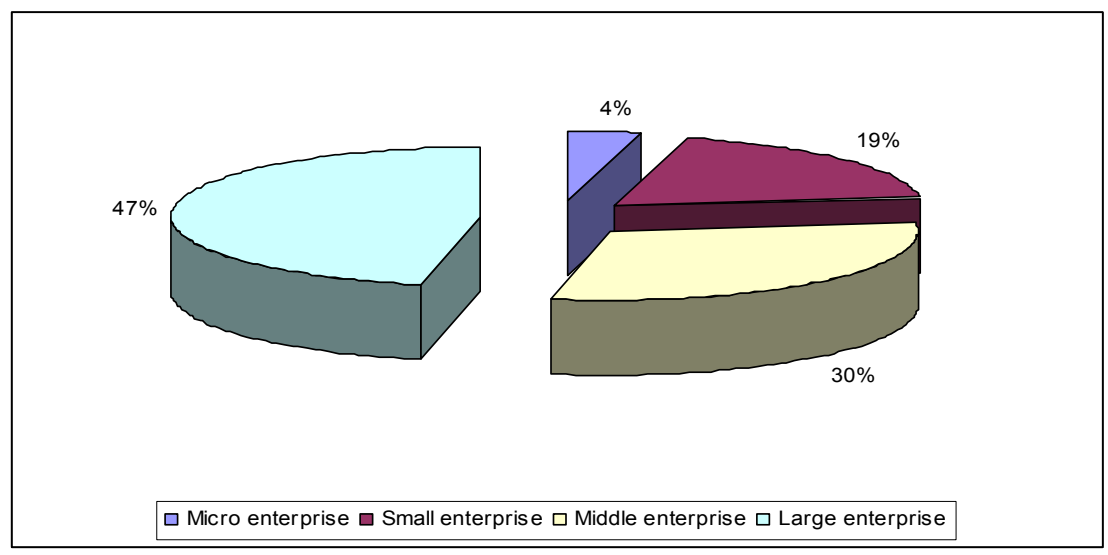

Figure 1 - Structure of organisations according to size

$87 \%$ of the surveyed organizations had implemented a quality management system (QMS) and 13\% did not. In terms of further investigation, we only dealt with organizations with the implemented QMS. These were further divided depending on the model of QMS. The first group consisted of organizations with the system introduced by ISO 9001, the second group were the organizations that have systems certified according to specification TS 16949 and in the third group were organizations focused on the military industry with the system introduced by the Allied Quality Assurance Publications (AQAP) model. The structure of surveyed organizations under this division is shown in Figure 2. 


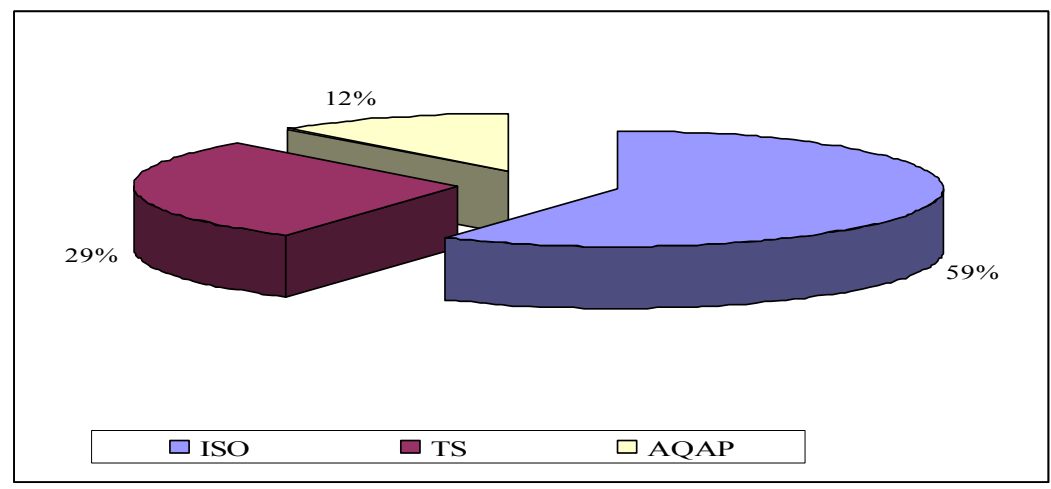

Figure 2 - Structure of organisations according to SMK

Questions in the questionnaire were formulated on the basis of normative document requirements for quality systems with a focus on using eight basic principles of quality management. Six to eight questions for each principle were specified in the questionnaire. Each question had a separate evaluation in the form of an absolute rate of individual responses and in some also with a varying percentage. Quantification of the responses was completed by the graphical representation.

Based on questionnaires from which we obtained interesting results, we can conclude that in the set of surveyed organizations, the application of the basic principles of total quality management was at quite a good level. Regarding the evaluation of individual policies, not all areas with each principle are implemented in business practice sufficiently or on the desired level. Striking differences among individual sectors were not found, although in some areas smaller or larger differences in the application of the quality management principles were shown. These differences mostly result from the specific conditions of the industry, i.e. automotive and military industries. The best level of the quality management principles application is in the automotive industry, which logically results from the more strict requirements in technical specification TS16949.

Based on the results of the survey may be stated that in the process management, respectively process approach, the attention is devoted mostly to implementation processes (process in production). They are also quite clearly identified and described. The main objective of the procedural approach is to encourage efficiency and effectiveness of the organization in achieving the stated objectives (Nenadál, Noskievičová, Petříková, and Tošenovský, 2008).

The analysis raised the following key issues which have become the basis for the design of measures for a better and more consistent application of the quality management principles with an aim to improve the efficiency and effectiveness of quality management (Paulová et al., 2010): 
- the surveying of customer requirements, is insufficient in practice,

- monitoring of the customer's satisfaction is not implemented systematically, the customer's satisfaction is not reflected by the quantitative indicators and results from monitoring are not used in the proper extent for improving the processes,

- management of the organizations is not involved into the managerial processes to the necessary extent,

- only half of the surveyed organizations have drawn up a code of ethics,

- insufficient attention is given to organizations in building a corporate culture, organizations have not clearly defined the objectives in this area,

- communication with employees is not at the required level and management is not sufficiently interested in its effectiveness,

- about one third of organizations have not designated process owners for all processes,

- the process maps are poorly used for the description of processes and the software support for process management is hardly used,

- the term internal customers in practice is not widely known or applied,

- in business practice it is barely used by the Balanced Score Card (BSC) method and for measuring and monitoring of the system performance of the very few organizations that apply a self-assessment and management review,

- significant shortcomings are in applying decision-making principles that are based on the facts because many organizations do not carry out a systematic collection of data, do not apply statistical methods in analyzing them and do not exploit the results of the analysis in at a sufficient rate for decisions on management improvement activities,

- not all organizations correctly understand the partnership with suppliers and effective communication throughout the product's design, as mentioned- less than half of the organizations,

- deficiencies are in the application of the principle of continuous improvement, because improvement projects are planning for only about one third of surveyed organizations,

- in practice, it is hardly implemented and the proactive improvement staff are inadequately trained and instructed with methods and tools for improvement,

- the application of various tools, techniques and methods in quality management in industrial enterprises is unsatisfactory. 
Based on the identified problems or poorly implemented activities related to the application of the fundamental principles of quality management, we suggested the possibility of separately increasing the level of their application in business practice for each principle. In elaborating the proposals, we focused on those areas where we found significant deficiencies or discrepancies and also on those which we consider the most important aspects for the further development of quality management in industrial enterprises. This issue is elaborated in detail in the publication of the same name, which was issued at the end of the research tasks solution. This paper presents the most relevant solutions to our task.

\section{SUGGESTIONS FOR IMPROVING THE EFFECTIVENESS OF QUALITY MANAGEMENT}

The duty of every organization that has implemented a quality management system is the implementation of continuous quality improvement through the improvement of all processes and activities in various stages of the production cycle. The organization must continually improve the effectiveness of the quality management system through the use of a quality policy, quality objectives, audit results, analysis of data, corrective and preventive actions and a review by management.

The applied principle of continuous improvement based on a survey is considered by us to be one of the weakest areas dealt with by quality management in corporate practice. This principle is very closely linked to other principles of quality management and covers all areas or activities of the organization. Weaknesses of other principles that applied to quality management principles that emerged from the survey are: a lack of involvement of senior management to improve activities, non use of the system's measurements, nonsystematic monitoring of satisfaction, insufficient evaluation of suppliers, underutilized methods and tools for data analysis, lack of knowledge and competence of staff to apply these methods, low involvement of employees in process improvement is reflected in the application of the principle of continuous improvement.

Under the term continuous improvement, there should be seen activities that lead to the achievement of a new, yet not achieved level in all fields of activity within the organization. If an organization wants to be successful, it must continually develop and cannot be satisfied with its the current state. It follows a series of obligations that must be met, but also a number of advantages, which it ensures. One of them is to ensure the competitiveness towards the other organizations and to strengthen its own position on the market. The philosophy of continuous improvement must be applied throughout the organization. Management should continually seek opportunities to improve efficiency and effectiveness of processes of the organization, rather than waiting for a problem which reveals opportunities to improve. Improvements can cover a range from small continuous operations to long-term strategic improvement projects. The Organization has to 
have a process implemented for the identification and management improvement activities. Higher management must ensure that a commitment to continuous improvement has not compromised the quality policy and objectives relating to its quality. Suggestions for projects related to improvement in accordance with a decision based on facts within the organization can be obtained from different measurements and analysis, to be implemented within the management system, such as an examination of the needs and expectations of customers, management should review the analysis of the output data from the measurements of satisfaction and processes, from the records of the quality management system of self-assessment results and the like.

Improving the quality has to be understood as activities to increase capacity to meet customer requirements and expectations that can not be understood only in a restricted plane of technical specifications. It is absolutely necessary to understand quality in relation to such factors as productivity, flexibility, delivery terms, the minimization of costs and the like. In this sense, it should be implemented for the improvement of projects and organizations should use the appropriate methodology.

In terms of improving quality management, systems comes to the wide spread use of new methods and techniques that are still insufficiently being applied in Slovak industry and therefore the improvement of this situation requires a major effort of the concerned workers in individual organizations and also an increase in the initiatives of experts in the field of quality management when promoting new trends of quality management in business practice.

\section{TRENDS AND DIRECTION OF QUALITY MANAGEMENT}

The ideas for improvement take into account trends and the direction of quality management in accordance with the requirements that reflect the understanding of quality in a broader context, i.e. the "quality of life". To improve performance and competitiveness of industrial enterprises it will be necessary in practice to apply different methods and approaches that push the organization to new levels. The potential of all used methods will be efficient and functional in the event of the organization being managed by process (Paulová et al., 2010).

To increase the success and competitiveness of organizations we suggest progressive methods and approaches now be applied in practice, such as:

- integrated management system,

- application of total quality management,

- responsible business and sustainable development.

The organizations have to adapt to the requirements of the international market and changes of the management methods and business philosophy in order to 
withstand any tough competitive struggles and to achieve a sustainable development. In all areas of economic and social life there are increased demands on corporate behaviour and there is a growing interest in maintaining and improving the product quality, the environment and safety at work. Organizations should review their situation and should seek to establish the effective management systems (quality, environment and safety) by means that can create a highly efficient and effective integrated management system.

Comprehensive quality management is an attitude, a philosophy and also a continuous process which emphasizes personal responsibility of all workers seeking to continuously improve. It is also a business strategy that makes all the activities of the company the centre of attention for customer satisfaction. Its aim is the continuous improvement of business for customers, owners and employees. It combines a sharp decline in the cost of clean-up errors with improved customer service, significantly streamlines internal processes, increases business flexibility, provides greater certainty of terms and leads to a strengthened position in international competition. A binding precondition for the success of TQM is an avid management and systematic, versatile use of methods and tools of quality management.

Successes and failures of TQM concepts are usually the result of good or absent involvement of business management. Executives of all hierarchical levels must be passionate about for the successful TQM and based on this, the essential importance for enhancing the quality in the enterprise for customers, owners and employees has the cooperative style of management, reliability of own actions, clear definitions of objectives, role of responsibility, a clear focus on the requirements and expectations of internal and external customers, the continuous support of improvement measures at all levels and an appropriately structured regular review of its sections and executives.

Currently, there are expectations from the organization that in addition to satisfying customers, the benefit from the organization will also have all concerned parties to prioritize the organization's sustainable development. There is a shift from product quality to the quality of the organization, which aims to achieve sustainable development. Responsible business is a concept whereby the companies on a voluntary basis in their business operations, as well as their interaction with stakeholders, integration of social and environmental aspects, and everyone concerned in the way it affects the competitiveness of the organization. Through responsible business, almost any organization, in cooperation with their stakeholders, can be involved in balancing the economic, social and environmental objectives. In the debate on globalization, competitiveness and sustainable development, the responsible business is becoming an increasingly important aspect. 


\section{CONCLUSION}

Quality management is the number of activities that first begin by the implementation of strategic plans and end with everyday small improvements. Improvement has to be initiated and implemented at all levels. The success of various improvement projects is dependent on the commitment of top management and all staff and also on the consistent application of methods, tools and techniques that are important not only for management decisions but also for implementing activities aimed at improvement. Good knowledge is an important factor for the effective application of new trends, advanced methods and tools in industrial practice during real problem solving. Topics designed on the basis of theoretical knowledge and information from the corporate practice acquired during a research project are a contribution to the development of quality management theory and also contribute to the effective application of fundamental principles of quality management in business practice within Slovakia.

\section{AFFILIATION}

The paper is a part of research project VEGA No. 1/0229/08 Perspectives of quality management development in coherence with requirements of Slovak Republic market.

\section{REFERENCES}

Fidlerová, H., (2005). „Requirements for implementation of integrated management system“, In Proceedings of Management of human potential in enterprise, International scientific conference, 2., Žilina, EDIS, pp. 76-78, ISBN 80-8070-360-4.

Juran J. M., Blanton Godfrey A., (1998). Juran's Quality Handbook, Fifth edition, Singapore: McGraw-Hill Companies, ISBN 0-07-116539-8.

Nenadál, J., Noskievičová, D., Petř́ková, R., Tošenovský, J. (2008). Modern Quality Management. Praha: Management Press, ISBN 978-80-7261-186-7.

Paulová, I. et al. (2010). Perspektívy rozvoja manažérstva kvality v súvislosti s požiadavkami trhu Slovenskej republiky, Trnava: AlumniPress, ISBN 987-808096-129-9.

Vaňová, J., Kučerová, M. (2010). "Continuous improvement in quality management", In: RaDMI 2010 : 10th International conference "Research and development in mechanical industry". Proceedings, Vol. 2., Donji Milanovac, Serbia, 16-19. September 2010, Vrnjačka Banja: SaTCIP, pp. 975-978, ISBN 978-86-6075-018-3.

ISO 9001:2008, Quality Management Systems - Requirements. 
ISO TS 16949 Quality management systems - Particular requirements for the application of ISO 9001:2000 for automotive production and relevant service part organizations.

\section{ABOUT THE AUTHORS \\ Marta Kučerová, $\mathrm{PhD}$. - senior lecturer at the Institute of Industrial Engineering, Management and Quality, Faculty of Materials Science and Technology in Trnava, Slovak University of Technology in Bratislava. The author is committed and engaged in publishing in the field of quality management, improvement of processes, application of statistical tools and techniques of quality management in industrial plants. \\ e-mail: marta.kucerova@stuba.sk}

Jaromíra Vaňová, $\mathrm{PhD}$. - senior lecturer at the Institute of Industrial Engineering, Management and Quality, Faculty of Materials Science and Technology in Trnava, Slovak University of Technology in Bratislava. The author is committed and engaged in publishing in the field of plant management, plant economy, corporate culture and quality management. e-mail: jaromira.vanova@stuba.sk

Dagmar Rusková, PhD. - senior lecturer at the Institute of Engineering Pedagogy and Humanities, Faculty of Materials Science and Technology in Trnava, Slovak University of Technology in Bratislava. The author is engaged in translating and interpreting economical and technical papers, monographs and teaching English for Specific Purposes.

e-mail: dagmar.ruskova@stuba.sk 